\title{
BUSINESS MODEL DEVELOPMENT OF A FRESH MILK AGRO-INDUSTRY IN RURAL AREAS
}

\author{
Hanik Atus Sangadah*)1, Machfud ${ }^{* *}$, Elisa Anggraeni**) \\ ${ }^{*}$ Agro-industrial Engineering, Postgraduate School, IPB University \\ Jl. Dramaga, Darmaga Campus, Bogor, 16680, Indonesia \\ ${ }^{* *}$ Department of Agro-industrial Technology, Faculty of Agricultural Technology, IPB University \\ Jl. Dramaga, Darmaga Campus, Bogor, 16680, Indonesia
}

\begin{abstract}
This research aims to identify several business models of fresh milk agro-industry that are emerging in rural areas, as well as factors that influence agro-industry development, and establish a dairy agro-industry business model framework. The case study method used in this research consists of an agro-industry with business models and cooperatives. According to the finding of this research, there are seven supporting factors that influence the growth of the fresh milk agro-industry in rural areas, that are; (1) organizational structure, (2) fresh milk handling operations, (3) technology application for production activities, (4) training of employees and breeders, (5) product marketing strategies, (6) product quality and quality assurance, (7) company actor's innovation. These seven factors can be determined using the weight ratio to assess the value of each factor that influences the development of the fresh milk agro-industry in rural areas, namely business management $(0.2641)$, raw material handling $(0.1510)$, and quality assurance $(0.1347)$. The importance of the decision is a crucial factor in the development of the dairy agro-industry in rural areas. In rural areas, the fresh milk agro-industry business model is a cooperative form of business, as well as a business model that incorporates both private and cooperative business practices. The more varied the business models examined, the stronger the fresh milk agro-industrial business model system would be. Since they help small-scale milk farmers in rural areas market their products, regional milk cooperatives are still the best business model to use.
\end{abstract}

Keywords: business model, BMC (Business Model Canvas), cross-case analysis, fresh milk agro-industry, multiple case study

\begin{abstract}
Abstrak: Tujuan dari penelitian ini adalah mengidentifikasi beberapa model bisnis agroindustri susu segar yang berkembang di pedesaan, mengidentifikasi faktor-faktor yang berpengaruh dalam pengembangan agroindustri, serta menyusun kerangka model bisnis agroindustri susu segar di pedesaan. Metode studi kasus berganda digunakan dalam penelitian ini terdiri dari agroindustri dengan model bisnis koperasi dan swasta. Berdasarkan hasil penelitian ini didapatkan tujuh faktor pendukung yang berpengaruh untuk pengembangan agroindustri susu segar di pedesaan, yaitu; (1) kemampuan mengelola organisasi, (2) aktivitas penanganan susu segar, (3) penerapan teknologi untuk kegiatan produksi, (4) pelatihan karyawan dan peternak, (5) strategi pemasaran produk, (6) jaminan mutu dan kualitas produk, (7) kreativitas pelaku usaha. Tujuh faktor tersebut kemudian dinilai dengan penilaian perbandingan berpasangan untuk menghitung bobot faktor penting yang berpengaruh dalam pengembangan agroindustri susu segar di pedesaan yaitu manajemen pengelolaan usaha $(0,2641)$, penanganan bahan baku $(0,1510)$, dan jaminan kualitas $(0,1347)$. Ketiga faktor hasil penilaian merupakan faktor penting yang harus diperhatikan dalam mengembangkan agroindustri susu di pedesaan. Usulan model bisnis agroindustri susu segar di pedesaan adalah koperasi sebagai bentuk usaha dan model bisnis yang dijalankan merupakan kombinasi dari praktik baik bisnis privat dan koperasi. Semakin beragamnya model bisnis yang diteliti akan memberikan peluang susunan kerangka model bisni agroindustri susu segar yang semakin baik. Koperasi susu daerah masih menjadi bentuk usaha yang tepat diterapkan karena mengakomodir peternak susu skala kecil di pedesaan dalam memasarkan hasil produksinya.
\end{abstract}

Kata kunci: model bisnis, Business Model Canvas (BMC), analisa lintas kasus, agroindustri susu segar, studi kasus berganda

${ }^{1}$ Corresponding author:

Email: hanik_atus@apps.ipb.ac.id 


\section{INTRODUCTION}

The amount of national milk production in Indonesia is $996,442.44$ tons of fresh milk with a domestic consumption rate of $3.53 \mathrm{~kg} / \mathrm{capita} /$ year (BPS, 2019). The level of national demand for milk reaches 4.3 million tons, and domestic production can only meet about 22 percent of national demand and the rest is met by imports. Nugroho (2010) states that 90 percent of the National Domestic Milk (SSDN) production is currently produced by smallholder businesses with a business scale of 2-3 cows per farmer. Efforts to increase domestic fresh milk production must be accompanied by improved livestock business management, starting from the cultivation of superior cows, using technology for milk production, to improving animal feed. Large industries consume the freshest milk, followed by households, restaurants, catering, and home businesses. According to BPS data from 2017, the highest consumption rate was 76.63 percent for Large Medium Industry (IBS), 6.28 percent for direct household consumption, 12.15 percent for food and beverage manufacturing companies, and 4.94 percent for hotel and health services. This percentage indicates that the fresh milk agro-industry has room to develop. The expansion of dairy farming and the development of the fresh milk agro-industry are inextricably linked. The rural fresh milk agro-industry has the potential to grow because it has the potential to improve the quality of life of small farmers by providing additional sources of income (Manuela et al. 2012). The business model is one of the things that can be done to help the agroindustry develop. The business model describes how the company conducts business, or how the company creates, delivers, and captures value (Teece, 2010).

Previous dairy agro-industry research focused on the analysis of the added value of fresh milk, marketing management of cow's milk, the fresh milk supply chain, strategic management of milk cooperatives, and efforts to improve milk quality. The research on the development of the dairy agro-industry village is focused on determining the priority of dairy products, product diversification based on consumer expectations, and training in dairy product processing (Agung, 2017). Meanwhile, studies on developing business models for the dairy agro-industry in rural areas are still uncommon. The importance of developing an appropriate business model framework for the rural dairy agro-industry is then highlighted in this study. Businesses are expected to benefit from business model innovation to survive and win in business competition. Business model innovation serves several important functions, including the ability to assess future resources that have not been utilized by the company; competitors find it more difficult to imitate a whole new activity system than they do new products or processes, and business models can be one of the competitive factors.

The research method used multiple case study methods, with data processing analysis using within analysis and cross-case analysis methods (Yin, 2014). This research was carried out on several case studies of the fresh milk agro-industry developing in rural areas to identify the agro-industrial business model that is developing in rural areas, to discover the factors that support the business model that has been compiled, and to discover the best business model arrangement to develop the fresh milk agro-industry in rural areas.

The purpose of this research is to investigate the rural dairy agro-industry business model and to propose a business model design for the rural dairy agro-industry. The findings of this study are expected to aid in the growth of the agro-industry. The composition of the business model framework generated by this study is hoped to play a role in encouraging the growth and development of the fresh milk agro-industry in rural areas. Furthermore, it is hoped that it will contribute to the fresh milk agro-industry or business itself, as well as serve as input to stakeholders in making decisions for the development of the fresh milk agro-industry in rural areas.

\section{METHODS}

From January to May 2020, case studies were conducted at (1) Koperasi Serba Usaha Mitra Jaya Mandiri (KSU MJM), Ciwidey (2) Yoos Yoghurt and Ciwidey Berkah, Ciwidey (3) Keju Indrakila, Boyolali, (4) Koperasi Peternak Sapi Bandung Utara (KPSBU), Lembang. The case study research was chosen based on some predetermined criteria, including being located in a rural area with the potential for fresh milk production from small-scale farmers, having the opportunity to develop, having a clear history of business development and respondents with experience, knowledge, and understanding of the business process. Aside from meeting several criteria, the willingness of the agroindustry to be the subject of research is also a factor in determining the research location. 
This study is a descriptive qualitative study with multiple case studies, and the business model of each case study serves as the primary data source for describing the case study research's business conditions. The author collects primary and secondary data from respondents through literature studies, interviews, and in-depth interviews. The resulting data is in the form of information on the composition of the business model for each case study, supporting factors that influence the development of the fresh milk agro-industry in rural areas, and business success indicators that can be used to evaluate the appropriate business model.

Data collection is carried out in accordance with the previous research protocol. Components of a business model that are developed through research include eight components such as product, customer interface, infrastructure management, and financial aspects (Osterwalder, 2004). A business model is a strategy for communicating the value of a company's product, its operations, and its competitive advantage (Atonela and Carrion, 2015).

In qualitative research, both single and multiple case study research techniques are frequently used to identify and select sources of information (Etikan et al. 2016). Several case studies have been used in studies, such as qualitative case studies of rural agricultural entrepreneurship network development (Adro and Franco, 2020), research on the determinants of successful biogas production in Swedish agriculture (Karlsson et al. 2017), innovation of sustainable business models with agricultural case studies in Sweden (Karlsson et al. 2016), and research on marketing stratification (Vergamini et al. 2019).

Researchers selected case studies based on several criteria, including being in a rural area with the potential for fresh milk production from small-scale farmers, having the opportunity to develop, having a clear history of business milestones, and having experience, knowledge, and understanding of their business processes. Aside from meeting some of these criteria, the agro-willingness industry is to be the subject of research and deciding where to conduct the research.

The research was carried out between January and May 2020, with four case studies as the subject of this study: (1) Mitra Jaya Mandiri Multi-Purpose Cooperative (KSU MJM) in Ciwidey, Bandung; (2) Yoos Yoghurt and Ciwidey Berkah in Ciwidey, Bandung; and (3)
Indrakila Cheese, Boyolali, and North Bandung Cattle Breeders Cooperative (KPSBU), Lembang. West Java and Central Java were chosen because, according to BPS data, West Java produced 351,885 tons of milk in 2019, and Central Java produced 100,799 tons. Keju Indrakila was chosen because it is one of the dairy agro-industries in Boyolali Regency that produces natural cheese. Ciwidey Berkah and Yoos Yoghurt were chosen as case studies because they are dairy businesses run by farmers, and the business ideas came from the training.

Respondents with expertise and business experience who can provide the required information following the research data collection guidelines are considered research respondents. The research guide takes the form of broad questions used to collect information about general business characteristics, business manager characteristics, business models run by business units, and factors that support the development of the fresh milk agro-industry in rural areas. The four components of a business model investigated using research guidelines are product, customer interface, infrastructure management, and financial aspects. (Osterwalder, 2004). Business models are concerned with strategies for explaining the worth of a company's product, its performance, and its competitive advantage (Atonela and Carrion, 2015). The development of the agro-industry sector upstream will positively impact business development, such as in the capture fisheries sector (Zulbainarni and Khumaera, 2020). Product describes the value proposition that the business unit provides to customers. The customer interface describes who the target consumers are, how the product's value reaches consumers, and what efforts are made to establish good relationships with consumers. Infrastructure management describes a business unit's activities to create product value, collaborate to create and deliver products, and use resources. The financial aspects of income and expenses incurred. Proceed with a cross-case analysis after obtaining a business model arrangement for each case study.

In qualitative research, both single and multiple case study research techniques are frequently used to identify and select sources of information (Etikan et al. 2016). Several case studies have been used in studies, such as qualitative case studies of rural agricultural entrepreneurship network development (Adro and Franco, 2020), research on the determinants of successful biogas production in Swedish agriculture 
(Karlsson et al. 2017), innovation of sustainable business models with agricultural case studies in Sweden (Karlsson et al. 2016), and research on marketing stratification (Vergamini et al. 2019). The author collects primary and secondary data from respondents through literature studies, interviews, and in-depth interviews. The resulting data is in the form of information on the composition of the business model for each case study, the supporting factors that influence the development of the fresh milk agro-industry in rural areas, and the achievement of business success indicators used to evaluate the appropriate business model.

Analyzing and processing data:

a. Development of the Fresh Milk Business Model in Rural Areas (Each case study contains the case/ within the analysis and a business model arrangement represented in the framework of a business model. Within the analysis, the business model of each case study is thoroughly examined so that the similarities and contrasting differences between the case studies can be seen).

b. Fresh Milk Agroindustry Development Factors Identification and Weighting (The composition of the influencing factors in developing the fresh milk agro-industry in rural areas is then weighted to yield three significant and influential factors).

c. Create a Business Model Framework (The agroindustry business model is developed through crosscase analysis, which compares components with similarities and differences before concluding).

\section{RESULT}

The case studies of fresh milk agro-industry in the villages selected for this research are (1) Koperasi Serba Usaha Mitra Jaya Mandiri (KSU MJM), (2) Ciwidey Berkah and Yoos Yoghurt, (3) Keju Indrakila, (4) Koperasi Peternak Sapi Bandung Utara (KPSBU). KSU MJM and KPSBU are cooperatives that have a primary focus on marketing quality fresh milk. KSU MJM markets milk to KPSBU then marketed to the Milk Processing Industry (IPS). Ciwidey Berkah and Yoos Yoghurt process milk into caramel candy and yoghurt products. Fresh milk as the main raw material is obtained from Ciwidey breeders who are MJM KSU. Keju Indrakila is a company that turns fresh milk into a variety of natural cheese products. Both case studies are part of a business unit that operates under a private ownership business model.

\section{Each Case Study's Fresh Milk Agroindustry Business Model}

The case analysis findings (within analysis) are used for cross-case analysis with other case studies. The preliminary analysis results begin with the observation of business characteristics, as shown in Table 1. Starting with the age of the business, the number of employees, and sales turnover, business characteristics can be used to see how the business conditions of each case study are studied.

Table 1. Characteristics of case research studies

\begin{tabular}{|c|c|c|c|c|}
\hline & KSU MJM & KPSBU & $\begin{array}{c}\text { Ciwidey Berkah \& Yoos } \\
\text { Yoghurt }\end{array}$ & Keju Indrakila \\
\hline The Age of business & 13 years & 49 years & 3 years & 10 years \\
\hline Type of business & cooperative & cooperative & private & private \\
\hline Start-up capital & $\begin{array}{c}\text { Member capital and } \\
\text { loans }\end{array}$ & $\begin{array}{c}\text { Member capital and } \\
\text { loans }\end{array}$ & Owner's equity & $\begin{array}{c}\text { Owner's equity and } \\
\text { loans }\end{array}$ \\
\hline Labor & 16 person & 225 person & 7 person & 8 person \\
\hline $\begin{array}{l}\text { Sales turnover } \\
(\text { period 2019) }\end{array}$ & $\left.\operatorname{Rp} 7.242 .992 .532^{*}\right)$ & Rp 392.655.998.110*) & $\begin{array}{r}\text { Rp52.860.000 } \\
\left(_{(\text {Ciwidey Berkah) }}^{* *}\right) \\
\text { Rp8.006.250 } \\
\left.(\text { Yoos Yoghurt) })^{* *}\right)\end{array}$ & $\left.\operatorname{Rp} 1.249 .860 .000^{* * *}\right)$ \\
\hline
\end{tabular}

Information:

*) sales turnover of fresh milk for the period 2019

**) product sales turnover for the end of 2019

${ }^{* * *}$ sales turnover of mozzarella products ( $80 \%$ of total production) for the 2019 period 
According to the analysis, the KSU MJM and KPSBU have a cooperative business model. Ciwidey Berkah, Yoos Yogurt, and Keju Indrakila are all privatelyowned companies. The working capital of privately owned business units is derived from both personal capital and loans. Privately owned business units can easily develop because they have management flexibility without involving members, as cooperatives do. The two business units in this research's case study are still relatively new, so the number of employees is still constrained by selling the product.

The product components in the business model are summarized in Table 2. KSU MJM and KPSBU offer comparable products in quality fresh milk that is ready for distribution to consumers. KPSBU has established a business unit that converts fresh milk into yoghurt. Meanwhile, the MJM KSU does not yet have a cooperative-managed milk processing unit. Dairy products are available through the Ciwidey Berkah, Yoos Yoghurt, and Cheese Indrakila business units.

Table 3 shows that the cooperative's main product is fresh milk, with large industries as its primary target consumers. Meanwhile, privately owned business units continue to sell processed goods to the general public as well as cafes and restaurants. The four case studies with quality assurance and product quality attempt to fulfil customer loyalty. Distribution is still done with its fleet, and promotions are done through social media platforms like Instagram, Facebook, and WhatsApp. Marketing has also begun to evolve through the use of online platforms such as a shopee.

Table 2. Cross-case analysis case study of product components

\begin{tabular}{|c|c|c|c|c|}
\hline KSU MJM & KPSBU & $\begin{array}{c}\text { Ciwidey Berkah \& } \\
\text { Yoos Yoghurt }\end{array}$ & Keju Indrakila & Conclusion \\
\hline $\begin{array}{l}\text { The main product } \\
\text { offered to customers } \\
\text { is high-quality fresh } \\
\text { milk from Ciwidey } \\
\text { breeders. }\end{array}$ & $\begin{array}{l}\text { North Bandung } \\
\text { breeders } \\
\text { and regional } \\
\text { cooperatives } \\
\text { produce fresh milk } \\
\text { of high quality } \\
\text { that meets major } \\
\text { industry standards. }\end{array}$ & $\begin{array}{l}\text { Ciwidey breeder milk } \\
\text { products include } \\
\text { yoghurt, greek, } \\
\text { caramel milk candy }\end{array}$ & $\begin{array}{l}\text { Fresh mozzarella, } \\
\text { Boyobert cheese, original } \\
\text { mountain cheese, } \\
\text { mountain chilli cheese, } \\
\text { feta cheese, and black } \\
\text { pepper feta cheese are } \\
\text { among the natural cheese } \\
\text { varieties available. }\end{array}$ & $\begin{array}{l}\text { Cooperative: } \\
\text { Fresh milk that meets } \\
\text { quality standards, } \\
\text { as well as processed } \\
\text { products, are being } \\
\text { developed. } \\
\text { Private: Various } \\
\text { processed products } \\
\text { derived from high- } \\
\text { quality milk }\end{array}$ \\
\hline
\end{tabular}

Table 3. Cross-case analysis case study of customer interface components

\begin{tabular}{|c|c|c|c|c|}
\hline KSU MJM & KPSBU & $\begin{array}{l}\text { Ciwidey Berkah \& } \\
\text { Yoos Yoghurt }\end{array}$ & Keju Indrakila & Conclusion \\
\hline $\begin{array}{l}\text { Industry and larger- } \\
\text { scale cooperatives } \\
\text { are the primary } \\
\text { consumers. Quality } \\
\text { fresh milk is } \\
\text { maintained through } \\
\text { quality control and } \\
\text { distributed by the } \\
\text { owned fleet, consisting } \\
\text { of trucks outfitted with } \\
\text { cooling tanks ranging } \\
\text { in capacity from } 1000 \\
\text { to } 4000 \text { L. }\end{array}$ & $\begin{array}{l}\text { Large-scale milk } \\
\text { processing industries } \\
\text { are the primary } \\
\text { consumers. You are } \\
\text { in charge of milk } \\
\text { distribution. with } \\
\text { its fleet of trucks } \\
\text { outfitted with 1000- } \\
5000 \text { L coolant } \\
\text { tanks and processed } \\
\text { products distributed } \\
\text { through cooperative } \\
\text { outlets }\end{array}$ & $\begin{array}{l}\text { Marketing via } \\
\text { resellers, relatives, } \\
\text { and gift shops } \\
\text { distributed by car } \\
\text { or delivery service } \\
\text { Consumers receive } \\
\text { bonuses after } \\
\text { spending a certain } \\
\text { amount of money. }\end{array}$ & $\begin{array}{l}\text { Cafés and restaurants } \\
\text { are the primary } \\
\text { consumers, and } \\
\text { distribution is either } \\
\text { direct or via cargo. The } \\
\text { shop also serves as a } \\
\text { sales outlet. A warranty } \\
\text { guarantee covers } \\
\text { consumers if their } \\
\text { products are damaged } \\
\text { during the trip. }\end{array}$ & $\begin{array}{l}\text { Cooperative; } \\
\text { - Large dairy } \\
\text { processing industry } \\
\text { - Distribution by } \\
\text { truck with coolant } \\
\text { tank } \\
\text { - Product quality } \\
\text { assurance } \\
\text { Private; } \\
\text { Tourists, cafes and } \\
\text { restaurants are the } \\
\text { target consumers }\end{array}$ \\
\hline
\end{tabular}


Table 4 describes the management infrastructure component, which describes key resources, key partnerships, and key activities that support the case study business's operations. Stockbreeders, both members and non-members, play an important role in supplying fresh milk to the cooperative. Private business units supply fresh milk from cooperative or modern farms. The selling price of milk, which is influenced by the quality, encourages the cooperative always to perform quality control to ensure that the milk is of high quality until it reaches the consumer. Production facilities to maintain product quality are required with a large amount of capital. The cooperative can procure refrigeration machines and refrigerated trucks for milk distribution from farmers to cooperatives to industry. Cooperative partners, ranging from government agencies to private businesses, offer cooperative opportunities to benefit from various programs ranging from farmer training to employee training.

Small business units such as Ciwidey Berkah and Yoos Yoghurt have built a cooperation mechanism based on the relationship between raw material suppliers and consumers. Farmers and cooperatives supply fresh milk that meets quality standards for fat, TPC (Total Plate Count), and total solids. Ciwidey Berkah sells caramel milk candy products to several gift shops in the Ciwidey area, offering direct delivery and bonuses for large purchases.

Table 5 shows that the cost structure incurred is similar, such as employee salaries, electricity, and transportation costs. Business owners can participate in training in private business units, but training for employees and breeders is required in cooperatives. Farmer training focuses on how to raise and milk that meets hygiene standards, ensuring the quality of the milk. The majority of the cooperative's income comes from the sale of fresh milk to large processing industries. In contrast, the private business unit's income comes from the sale of the products it manufactures. Cooperatives that already have processed business units have additional income sources from the sale of processed products. There is also a distinction in the collection of business capital because the cooperative obtain capital and bank loans from the cooperative members' principal contributions.

Table 4. Cross-case analysis case study components of infrastructure management

\begin{tabular}{|c|c|c|c|c|}
\hline KSU MJM & KPSBU & $\begin{array}{c}\text { Ciwidey Berkah \& } \\
\text { Yoos Yoghurt }\end{array}$ & Keju Indrakila & conclusion \\
\hline $\begin{array}{l}\text { KSU members serve } \\
\text { as both partners } \\
\text { and suppliers. The } \\
\text { primary facilities are } \\
\text { transportation and } \\
\text { refrigeration. Every } \\
\text { time milk is received } \\
\text { at the cooperative, it is } \\
\text { tested for quality using } \\
\text { a milk analyzer. }\end{array}$ & $\begin{array}{l}\text { Excellent } \\
\text { collaboration with } \\
\text { members ranging } \\
\text { from large industries } \\
\text { to universities. } \\
\text { Training is always } \\
\text { used to improve } \\
\text { human resource } \\
\text { capabilities (such } \\
\text { as administration, } \\
\text { dairy husbandry } \\
\text { and technology } \\
\text { use, quality control, } \\
\text { accounting, artificial } \\
\text { insemination, and } \\
\text { animal health). A } \\
\text { steady supply of high- } \\
\text { quality, fresh milk. }\end{array}$ & $\begin{array}{l}\text { Ciwidey breeders } \\
\text { supply fresh milk } \\
\text { as raw material. } \\
\text { Collaborations with } \\
\text { breeders, gift shops, } \\
\text { and milk cooperatives } \\
\text { are formed. }\end{array}$ & $\begin{array}{l}\text { Has physical as well as } \\
\text { intellectual resources. } \\
\text { Worker's abilities } \\
\text { while on the job. } \\
\text { Contemporary livestock } \\
\text { as a source of fresh } \\
\text { milk. }\end{array}$ & $\begin{array}{l}\text { Cooperative; } \\
\text { - Farmers } \\
\text { - Cooling machine } \\
\text { - quality control } \\
\text { Private; } \\
\text { - modern farms } \\
\text { - production activities } \\
\text { - intellectual-property }\end{array}$ \\
\hline
\end{tabular}


Following current business capabilities, each business unit has financial aspect management. Ciwidey Berkah and Yoos Yoghurt continue to do manual bookkeeping, recording business income and expenses. Meanwhile, the KSU MJM and KPSBU have more comprehensive financial management, including an accounting section and an operating income statement written and reported annually in the RAT (Annual Budget Meeting) agenda. Keju Indrakila also has a more efficient financial report administration system that its employees manage. The cross-case analysis is also used to obtain summary indicators for business success. Table 6 summarizes business performance metrics.

Figure 1 depicts the measure of business performance of the production growth of the KSU MJM, KPSBU, and Keju Indrakila. KPSBU has also developed an information system that is used to track fresh milk and products. Meanwhile, the suitability of processed milk products is ensured, beginning with raw materials for fresh milk and continuing with the use of production raw materials following food safety standards, without the addition of preservatives or other hazardous food additives.

Marketing coverage, increasing the number of productions, product diversity, increasing turnover and number of workers, reducing the risk of reject products, and fulfilling product quality assurance according to predetermined standards are all indicators of each case study's success in running a business. Business performance indicators can be realized by fulfilling factors that aid in the growth and development of the agro-industry.

Table 5. Cross-case analysis case study of financial aspect components

\begin{tabular}{|c|c|c|c|c|}
\hline KSU MJM & KPSBU & $\begin{array}{c}\text { Ciwidey Berkah \& } \\
\text { Yoos Yoghurt }\end{array}$ & Keju Indrakila & Conclusion \\
\hline $\begin{array}{l}\text { The sale of fresh } \\
\text { milk generates } \\
\text { revenue. Electricity, } \\
\text { employee salaries, } \\
\text { and transportation } \\
\text { costs are examples of } \\
\text { routine expenses. }\end{array}$ & $\begin{array}{l}\text { The sale of fresh milk } \\
\text { to the industry and } \\
\text { the sale of processed } \\
\text { products generate } \\
\text { revenue. Employee } \\
\text { salaries, electricity, } \\
\text { transportation costs, } \\
\text { and training costs are } \\
\text { all covered by the } \\
\text { costs incurred. }\end{array}$ & $\begin{array}{l}\text { Product sales generate } \\
\text { revenue. } \\
\text { The costs incurred } \\
\text { include distribution } \\
\text { costs, employee } \\
\text { salaries, raw material } \\
\text { provision, and } \\
\text { additional materials. }\end{array}$ & $\begin{array}{l}\text { Revenue is generated } \\
\text { through the sale of } \\
\text { cheese products and } \\
\text { partner merchandise. } \\
\text { Costs incurred for shop } \\
\text { rent, employee salaries, } \\
\text { the purchase of } \\
\text { production materials, } \\
\text { the procurement } \\
\text { of equipment, and } \\
\text { licensing. }\end{array}$ & $\begin{array}{l}\text { cooperative; } \\
\text { Income: sales of fresh } \\
\text { milk } \\
\text { Expenses: employee } \\
\text { salaries, training, } \\
\text { equipment procurement } \\
\text { Private; } \\
\text { Revenue: sales of } \\
\text { products } \\
\text { Expenses: licensing } \\
\text { fees, production costs, } \\
\text { shop rent }\end{array}$ \\
\hline
\end{tabular}

Table 6. Conclusion of the results of cross-case analysis of business performance indicators

\begin{tabular}{|c|c|}
\hline Indikator & Conclusion \\
\hline Production growth & Production growth is only experienced by KPSBU and Keju Indrakila, \\
\hline Increase in sales turnover & $\begin{array}{l}\text { Sales turnover growth is in line with production growth and occurs at KPSBU and Keju } \\
\text { Indrakila. }\end{array}$ \\
\hline Employee development & $\begin{array}{l}\text { Only Yoos yoghurt has not experienced a growth in the number of employees / has not had } \\
\text { employees after } 3 \text { years of existence. }\end{array}$ \\
\hline Member expansion & The growth in the number of cooperative members occurred at KPSBU. \\
\hline Marketing reach expansion & $\begin{array}{l}\text { The growth of the marketing area has not occurred at Yoos Yoghurt, the area is still limited } \\
\text { in the Ciwidey neighbourhood through relatives. }\end{array}$ \\
\hline $\begin{array}{l}\text { Product differentiation is } \\
\text { increasing }\end{array}$ & KSU MJM and Ciwidey Berkah do not have a choice of product variants. \\
\hline Income source expansion & KPSBU has more diverse sources of income. \\
\hline $\begin{array}{l}\text { Development of product } \\
\text { innovation }\end{array}$ & $\begin{array}{l}\text { Keju Indrakila continues to be creative in developing new products in accordance with } \\
\text { consumer demand. }\end{array}$ \\
\hline $\begin{array}{l}\text { Capital expansion in } \\
\text { business }\end{array}$ & $\begin{array}{l}\text { KPSBU starts from member contribution capital, personal and cooperation with dairy cow } \\
\text { factories that develop with the government's help and several private agencies, both national } \\
\text { and international. } \\
\text { Keju Indrakila has additional business capital from the private sector by winning several } \\
\text { award competitions. }\end{array}$ \\
\hline
\end{tabular}




\section{Factors Contributing to the Development of the Agro-Industry}

Researchers identified seven important factors that support the operation of a rural fresh milk agro-industry based on the findings of this study. Table 7 describes the supporting factors for developing an agro-industry business model. According to several studies, market diversification and product development are the most influential factors in business development (Bonazzi and Zilber, 2014). Market diversification can be done with quality-based differentiation., diversify marketing channels, and target existing local and dominant markets (Vergamini et al. 2019). Furthermore, product development efforts can be carried out by developing new product innovations and involving active consumer participation (Markovic et al. 2020) (Qi et al. 2020).

After determining the influencing factors, the next step is to evaluate the pairwise comparison weighting to determine which important factors are extremely influential in developing the business unit. Three (three) respondents, namely the KPSBU management, the Indrakila Cheese manager, and a business development expert assess factor weight. Table 8 displays the pairwise comparison assessment results.

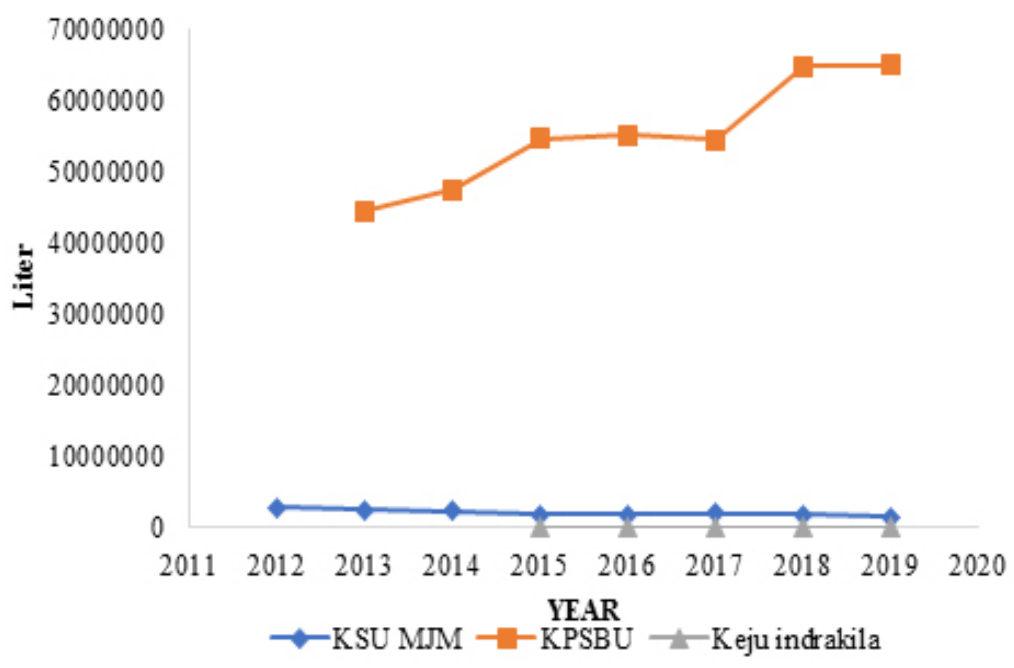

Figure 1. Growth in the number of production of KSU MJM, KPSBU, Keju Indrakila

Table 7. Influencing factors in the development of the fresh milk agro-industry

\begin{tabular}{|c|c|c|}
\hline \multicolumn{3}{|c|}{ Supporting factors } \\
\hline $\begin{array}{l}\text { A business unit with a cooperative } \\
\text { business model }\end{array}$ & A business unit with a private business model & Conclusion \\
\hline $\begin{array}{l}\text { - Manage a cow credit program for its } \\
\text { members. } \\
\text { - Manage cooperative membership } \\
\text { - Manage the price of fresh milk } \\
\text { purchased from farmers. } \\
\text { - Collaborate with several related parties } \\
\text { (universities, banks, government and } \\
\text { private agencies, GKSI). } \\
\text { - Manage assistance programs obtained } \\
\text { from various institutions. } \\
\text { - Established a fresh milk processing } \\
\text { business unit. } \\
\text { - Runs training programs for members } \\
\text { and administrators. } \\
\text { - Has infrastructure and facilities for } \\
\text { handling raw materials (pick-up fleet, } \\
\text { cooling machines, cooling chamber). } \\
\text { - The price of fresh milk determined by } \\
\text { the quality of the milk }\end{array}$ & $\begin{array}{l}\text { - Raw material handling is regarded as an } \\
\text { important factor influencing product quality. } \\
\text { - Production activities are still carried out } \\
\text { manually following current business } \\
\text { conditions. } \\
\text { - Business owners participate in training on the } \\
\text { manufacture of processed products to improve } \\
\text { their skills. } \\
\text { - The marketing system is still carried out by } \\
\text { utilizing relatives, is worth of word of mouth, } \\
\text { and does not have a formal marketing system. } \\
\text { - Keju Indrakila chooses to use manual } \\
\text { equipment to make it easier to manage labor } \\
\text { allocation. } \\
\text { - More diverse product variants (variations } \\
\text { in the flavors and sizes of caramel candy } \\
\text { products, the addition of cheese variants, and } \\
\text { the addition of flavors of yogurt products) } \\
\text { demonstrate the ability to innovate. }\end{array}$ & $\begin{array}{l}\text { 1. Organizational } \\
\text { management (workforce, } \\
\text { production facilities). } \\
\text { 2. Raw material handling } \\
\text { activities (fresh milk) } \\
\text { 3. Manufacturing } \\
\text { technology. } \\
\text { 4. Workforce training to } \\
\text { improve skills. } \\
\text { 5. Product marketing plan } \\
\text { 6. Quality assurance and } \\
\text { product quality. } \\
\text { 7. The inventiveness of in } \\
\text { developing new products. }\end{array}$ \\
\hline
\end{tabular}


Table 6. Conclusion of the results of cross-case analysis of business performance indicators

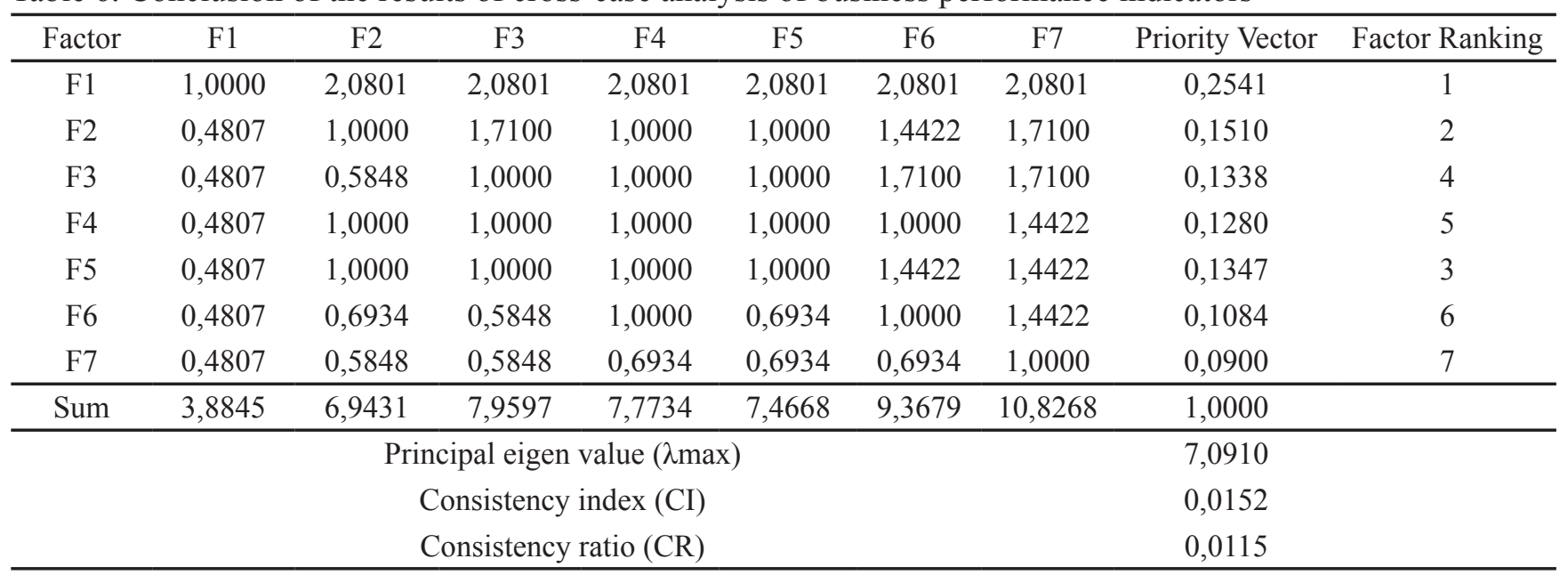

Information: F1(Organizational management); F2(raw material handling activities); F3(manufacturing technology); F4(workforce training); F5(quality and quality assurance); F6(marketing strategy); F7(creativity to create new products)

\section{The ability to lead an organization}

When capital providers choose a profitable business, their value and income will be maximized (Agustia et al. 2020). In order to help members reach markets with higher selling prices, agricultural cooperatives in developing countries provide a variety of services such as input supply, processing, product marketing, financing, and technology. It is critical for cooperatives to manage cooperative membership properly. The growing number of dairy cooperative/dairy farmer members will increase fresh milk production. Meanwhile, the private business unit manages its employees by paying them attenuated salaries.

\section{Handling of raw materials}

Because fresh milk is easily contaminated and damaged, the product must be handled quickly and adequately. Fresh milk handling activities begin with the farmer and include hand washing, udder washing, preparation before milking, handling after milking, and the type of container used to hold fresh milk (Kashongwe et al. 2017).

\section{Quality control and assurance}

Fresh milk quality assurance is inextricably linked to farm management. There is a strong link between access to animal health services and the adoption of feeding and breeding strategies that will improve milk quality. Improving the quality of fresh milk can be accomplished by increasing forage production, improving dairy cow genetics, and training farmers (Özkan Gülzari et al. 2020).

\section{Arrangement for Fresh Milk Agroindustry Business Model}

Based on the findings of the cross-case analysis, the design of a business model with the potential to be developed in rural areas is a combination of best practices from private and cooperative business models, as shown in Figure 2. The research outcome business model depicted in BMC component Figure 3 is a business model applied to other areas with similar or dissimilar characteristics. The business model is implemented by considering important factors that support the development of agro-industry in rural areas.

The characteristics of Indonesian livestock, which small-scale breeders dominate with 2-3 cows, serve as the foundation for developing an appropriate rural agroindustrial business model. The cooperative business model is a business model that is tailored to the needs of rural farmers. Dairy cooperatives in rural areas play an important role in disseminating new technology, receiving $R \& D$ results such as nutritious feed, animal vaccines, and superior cows. Cooperatives play an important role in improving people's quality of life and the welfare of their members and the community as a whole (Dogarawa, 2012).

Cooperatives are formed by groups of small farmers who require a stronger bargaining position in the market to negotiate prices and have actors in both the upstream and downstream sectors (Figueiredo \& Franco, 2018). Meanwhile, the private business units in this case study continue to face fresh milk absorption capacity constraints. The milk absorption capacity for 
production activities is proportional to the amount of product demand. Cooperatives with effective organizational management can increase the number of members as well as the amount of fresh milk produced. Cooperatives with effective organizational management can increase the number of members as well as the amount of fresh milk produced. Cooperatives as a dairy agro-industry will survive for a long time if the remunerative price of milk from farmers is reasonable, the value offered to consumers is reasonable, and there is a guarantee for the return of damaged products. Figure 2 depicts a business model framework that combines best practices from cooperative and private enterprises. Each component of the business model has a relationship that is interconnected. The development of products and value propositions necessitates the use of appropriate resources, activities, and partners. Quality raw material resources provided by business partners can help realize efforts to create processed milk products that meet quality standards. Production employees must also have processing skills and knowledge of raw material and product characteristics, and production activities must be carried out following hygiene standards. The channels used are determined by the target consumers' ownership, such as resellers, souvenir shops, or business unit-owned shops. Efforts to retain consumer loyalty are carried out by ensuring product quality.

The value provided by the compiled business model is high-quality fresh milk and dairy products. The amount of production is determined by the product's marketability and consumer demand. The guarantee of product and service quality and the replacement of products damaged during the trip is an attempt to maintain consumer loyalty. Key activities include developing products, communicating them to customers, and maintaining positive relationships with customers and partners. The main activities are milk quality control through proper handling of fresh milk, training to improve the competence of cooperative members and employees, and product certification to increase consumer confidence. One of the most important resources ensuring the sustainability of the fresh milk agro-industry is the supply of high-quality fresh milk. Aside from supply, physical resources for handling fresh milk are essential.

\begin{tabular}{|c|c|c|c|c|}
\hline $\begin{array}{l}\text { KEY PARTNERS } \\
\text { - Cooperative } \\
\text { member } \\
\text { - GKSI } \\
\text { - College } \\
\text { - Milk processing } \\
\text { industry and their } \\
\text { private institutions } \\
\text { related to the dairy } \\
\text { farming and agro- } \\
\text { industry }\end{array}$ & $\begin{array}{l}\text { KEY ACTIVITIES } \\
\text { - Procurement } \\
\text { of quality raw } \\
\text { materials and } \\
\text { production } \\
\text { activities } \\
\text { - Milk quality control } \\
\text { activities of milk } \\
\text { producers } \\
\text { - Farmers and } \\
\text { employees training } \\
\text { - Development of } \\
\text { new product } \\
\text { - Product promotion } \\
\text { and marketing }\end{array}$ & \begin{tabular}{|c|} 
VALUE \\
PROPOSITION \\
- Dairy products that \\
are produced meet \\
quality standards \\
- Dairy products have \\
various variants
\end{tabular} & $\begin{array}{l}\text { CUSTOMER } \\
\text { RELATIONSHIP } \\
\text { - } \text { Product quality } \\
\text { assurance and } \\
\text { product tracking } \\
\text { system } \\
\text { - } \text { Replacement of } \\
\text { damaged products } \\
\text { during transit } \\
\text { - Branding of products } \\
\text { produced from local } \\
\text { milk } \\
\text { - Giving bonus } \\
\text { purchases }\end{array}$ & $\begin{array}{l}\text { CUSTOMER } \\
\text { SEGMENTS } \\
\text { - Large dairy } \\
\text { processing industry } \\
\text { - Café dan Resto } \\
\text { - Tourists } \\
\text { - End consumers }\end{array}$ \\
\hline $\begin{array}{l}\text { COST STRUCTURE } \\
\text { - Production costs } \\
\text { - Overhead costs } \\
\text { - Training costs } \\
\text { - Investments }\end{array}$ & \multicolumn{4}{|c|}{$\begin{array}{l}\text { REVENUE STREAMS } \\
\text { - Sales of fresh milk } \\
\text { - Sales of dairy products } \\
\text { - Sales of partner products }\end{array}$} \\
\hline
\end{tabular}

Figure 2. Framework for business model arrangement 
Cooperatives have more open cooperation opportunities than private companies in this case study. Cooperatives form alliances with organizations ranging from government institutions to banks, breeders, cooperative members, universities, industry, and international organizations. Cooperatives can help improve market access and reduce the risk of product damage due to uncertainty in product purchases (Chagwiza et al. 2016). The cooperative's main source of income is the sale of fresh milk to the industry and the principal savings of the members. Cooperatives that already have a fresh milk processing unit can supplement their income by selling processed products. The cost structure issued by the cooperative and private is generally the same, beginning with production costs, overhead costs, employee salaries, and raw material purchases. It does, however, differ in terms of investment sources. Cooperatives have more diverse sources of business investment than private companies, which typically have their sources of capital from the business's private owners.

Dairy cooperatives in rural areas can manage the potential for fresh milk produced by small-scale farmers by constructing their fresh milk processing units, increasing the added value of the fresh milk produced. Cooperative membership has a positive impact, as evidenced by increased fresh milk production and cooperative income. Cooperatives always rely on training as a program. Training is an effort to develop human resources, whether training in the breeding or cultivation of dairy cows, training in the production of quality animal feed, training in pen management, or training in livestock health. Farmer training is provided in food safety practices ranging from animal health to hygienic milking, hygienic storage, and hygienic place maintenance (Kumar et al. 2018). The training is expected to improve the quality of fresh milk produced by farmers, thereby increasing the selling price of fresh milk. Cooperatives can also guide farmer groups on processing milk, allowing them to play a role in developing breeders' entrepreneurial spirit.

\section{Managerial Implications}

The findings of this study suggest that the framework of a business model can be used to develop a fresh milk agro-industry in rural areas. Cooperatives are the best type of business to develop, and the business models used are a hybrid of good practices for private business units and cooperatives. The value proposition, key partnerships, key resources, key activities, and cost structure are important components of a business model that must be considered following the business model's cross-case analysis framework.

\section{CONCLUSIONS AND RECOMMENDATIONS}

\section{Conclusions}

Cooperatives and the private sector are both attempting to create products that meet quality standards and ensure that quality products reach consumers from value creation. Cooperatives have the primary consumers, which are large processing industries, whereas the private sector has a broader target consumer based on the processed products produced. Distribution activities carried out directly by business units using a business unit fleet, focusing on handling raw materials and production to maintain product quality. The processed products produced have registered trademarks and deliver business value. Some dairy products, such as cheese, require additional certification to be sold outside of the island. The sale of products generates value capture for cooperatives and the private sector. The cooperative earns additional money from the sale of dairy products and livestock supplies, and it has a separate cost structure for training activities for both farmers and employees.

The seven identified factors contribute to developing a business model framework in which the cooperative is the appropriate business form for the fresh milk agroindustry in rural areas. The compiled business model combines private/entrepreneurship business practices and the cooperative's business model practices. Entrepreneurial creativity and the development of new products is some of the keys to successful business growth. Human resource management is an important point for agro-industrial development in the key resource component. The chosen technology resource is a manufacturing technology capable of increasing efficiency, lowering costs, and increasing market share. Key activities in a business model that should be prioritized include employee and cooperative member training, business management beginning with the procurement of high-quality raw materials, production activities, product development innovation, and the formulation of marketing strategies. Existing business models' collaboration networks must be expanded and strengthened. 


\section{Recommendations}

The development of the fresh milk agro-industry business model can be carried out in conjunction with other case studies to enrich the components further, and supporting factors used to compile the fresh milk agroindustry business model. The presence of other business models will also impact the outcome of the resulting business model arrangement. There are opportunities for different business models that could be generated with additional business model case studies that are not currently being investigated. A pilot project can validate the business model and determine the level of success of businesses that operate outside of the research area and have different characteristics.

\section{REFERENCES}

Adro F do, Franco M. 2020. Rural and agrientrepreneurial networks: A qualitative case study. Land Use Policy 99:105-117. https://doi. org/10.1016/j.landusepol.2020.105117.

Agustia D, Muhammad NPA, Permatasari Y. 2020. Earnings management, business strategy, and bankruptcy risk: evidence from Indonesia. Heliyon 6(2):303-317. https://doi.org/10.1016/j. heliyon.2020.e03317.

Agung. 2017. Fakultas peternakan dukung pengembangan desa agroindustri susu di Purwobinangun. Https://ugm.ac.id/id/news. [31 March 2021].

Atonela V, Carrion V. 2015. New business models: practical analysis of canvas model [tesis]. Spanyol: Degree in Business Administration, Universitat Jaume.

Bonazzi FLZ, Zilber MA. 2014. Innovation and business model : a case study about integration of innovation funnel and business model canvas. RBGN Revista Brasileira De Gestao De Negocios Review Of Bussiness Management 16(53):616-637.

Chagwiza C, Muradian R, Ruben R. 2016. Cooperative membership and dairy performance among smallholdersinEthiopia.FoodPolicy 59:165-173. https://doi.org/10.1016/j.foodpol.2016.01.008.

Dogarawa AB. 2012. The role of cooperative societies in economic development. SSRN Electronic Journal 1-20.

Etikan I, Musa SA, Alkassim RS. 2016. Comparison of Convenience Sampling and Purposive Sampling.
American Journal of Theoretical and Applied Statistics 5(1):1-4. https://doi.org/10.11648/j. ajtas.20160501.11.

Figueiredo V, Franco M. 2018. Wine cooperatives as a form of social entrepreneurship: Empirical evidence about their impact on society. Land Use Policy 79:812-821.

Karlsson NPE, Hoveskog M, Halila F, Mattsson M. 2016. Early phases of the business model innovation process for sustainability: Addressing the status quo of a Swedish biogas-producing farm cooperative. Journal of Cleaner Production 172:2759-2772.https://doi.org/10.1016/j. jclepro.2017.11.136.

Karlsson NPE, Halila F, Mattsson M, Hoveskog M. 2017. Success factors for agricultural biogas production in Sweden: A case study of business model innovation. Journal of Cleaner Production 142:2925-2934.https://doi.org/10.1016/j. jclepro.2016.10.178.

Kashongwe OB, Bebe BO, Matofari JW, Huelsebusch CG.2017.Associationsbetweenmilkingpractices, somatic cell counts and milk postharvest losses in smallholder dairy and pastoral camel herds in Kenya. International Journal of Veterinary Science and Medicine 5(1):57-64. https://doi. org/10.1016/j.ijvsm.2017.01.001.

Kumar A, Saroj S, Joshi PK, Takeshima H. 2018. Does cooperative membership improve household welfare? Evidence from a panel data analysis of smallholder dairy farmers in Bihar India. Food Policy 75:24-36. https://doi.org/10.1016/j. foodpol.2018.01.005.

Manuela M, Mckeller M, Smardon RC. 2012. The potential of small-scale agro-industry as a sustainable livelihood strategy in a caribbean archipelago province of Colombia the potential of small-scale agro-industry as a sustainable livelihood strategy in a Caribbean archipelago province of Colombia. Journal of Sustainable Development 5(3):16-33. https://doi. org/10.5539/jsd.v5n3p16.

Markovic S, Jovanovic M, Bagherzadeh M, Sancha C, Sarafinovska M, Qiu Y. 2020. Priorities when selecting business partners for service innovation: The contingency role of product innovation. Industrial Marketing Management 88:378-388.https://doi.org/10.1016/j. indmarman.2020.06.001.

Nugroho BA. 2010. Pasar susu dunia dan posisi Indonesia. Jurnal Ilmu-Ilmu Peternakan 20:65- 
76.

Osterwalder A. 2004. The business model ontology a proposition in a design science approach [tesis]. Switzerland: Des Hautes Etudes Commerciales, Universite De Lausanne.

Özkan Gülzari Ş, Owade JO, Ndambi OA. 2020. A review of interventions and parameters used to address milk quality in eastern and southern Africa. Food Control 116:107-300. https://doi. org/10.1016/j.foodcont.2020.107300.

Qi Y, Mao Z, Zhang M, Guo H. 2020. Manufacturing practices and servitization: The role of mass customization and product innovation capabilities. International Journal of Production Economics 228:107-747. https://doi. org/10.1016/j.ijpe.2020.107747.
Teece DJ. 2010. Business models , business strategy and innovation. Long Range Planning 43(2-3):172194. https://doi.org/10.1016/j.1rp.2009.07.003.

Vergamini D, Bartolini F, Prosperi P, Brunori G. 2019. Explaining regional dynamics of marketing strategies: The experience of the Tuscan wine producers. Journal of Rural Studies 72:136-152. https://doi.org/10.1016/j.jrurstud.2019.10.006.

Yin, R.K. 2014. Case Study Research Design and Methods. United States of America: SAGE Publications, Inc

Zulbainarni N, Khumaera NI. 2020. Root cause analysis on development of sustainable fisheries business in Indonesia. Jurnal Manajemen dan Agribisnis 17(1):33-41.https://doi.org/10.17358/ jma.17.1.33. 